\title{
Novel preparation method for sustained-release PLGA microspheres using water-in-oil-in- hydrophilic-oil-in-water emulsion
}

This article was published in the following Dove Press journal:

International Journal of Nanomedicine

5 July 2013

Number of times this article has been viewed

\author{
Xiaoyun Hong ${ }^{1,2, *}$ \\ Liangming $\mathrm{Wei}^{3, *}$ \\ Liuqing $\mathrm{Ma}^{2}$ \\ Yinghui Chen ${ }^{4}$ \\ Zhenguo Liu' \\ Weien Yuan ${ }^{2, *}$
}

'Department of Neurology, Xinhua Hospital affiliated to Shanghai JiaoTong University, School of Medicine, Shanghai, People's Republic of China; ${ }^{2}$ School of Pharmacy, Shanghai JiaoTong University, ${ }^{3}$ Key Laboratory for Thin Film and Microfabrication Technology, Ministry of Education, Research Institute of Micro/Nanometer Science and Technology, Shanghai JiaoTong University, Shanghai, People's Republic of China; ${ }^{4}$ Department of Neurology, Jinshan Hospital, Fudan University, Shanghai, People's Republic of China

*These authors contributed equally to this work

Correspondence: Yinghui Chen Department of Neurology, Jinshan Hospital, Fudan University, No 1508 Longhang Road, Jinshan District, Shanghai 201508, People's Republic of China

Tel +86 I89 308| 9605

Fax +8621341899905517

Email cyh1973131@163.com

Zhenguo Liu

Department of Neurology, Xinhua Hospital, Shanghai JiaoTong University School of Medicine, 1665 Kongjiang Road, Shanghai 200092, People's Republic of China

Tel +86 2I 2507750 I

Fax +86 21 65790000

Email zhenguoliu2004@aliyun.com

\begin{abstract}
An increasing number of drugs are needing improved formulations to optimize patient compliance because of their short half-lives in blood. Sustained-release formulations of drugs are often required for long-term efficacy, and microspheres are among the most popular ones. When drugs are encapsulated into microsphere formulations, different methods of preparation need to be used according to specific clinical requirements and the differing physicochemical characteristics of individual drugs. In this work, we developed a novel method for sustainedrelease drug delivery using a water-in-oil-in-hydrophilic oil-in-water $\left(\mathrm{w} / \mathrm{o} / \mathrm{o}_{\mathrm{h}} / \mathrm{w}\right)$ emulsion to encapsulate a drug into poly(lactic-co-glycolic acid) (PLGA) microspheres. Different effects were achieved by varying the proportions and concentrations of hydrophilic oil and PLGA. Scanning electron and optical microscopic images showed the surfaces of the microspheres to be smooth and that their morphology was spherical. Microspheres prepared using the $\mathrm{w} / \mathrm{o} / \mathrm{o}_{\mathrm{h}} / \mathrm{w}$ emulsion were able to load protein efficiently and had sustained-release properties. These results indicate that the above-mentioned method might be useful for developing sustained-release microsphere formulations in the future.
\end{abstract}

Keywords: protein, microspheres, water-in-oil-in-hydrophilic oil-in-water emulsion, sustainedrelease

\section{Introduction}

The physicochemical characteristics of different drugs vary considerably, so different microsphere formulations are often developed according to specific clinical need. Emulsion methods are most commonly used to prepare microspheres, eg, water-in-oil (w/o), ${ }^{1}$ water-in-oil-in-water (w/o/w), ${ }^{2,3}$ water-in-oil-in-oil (w/o/o), ${ }^{4}$ oil-in-water $(\mathrm{o} / \mathrm{w}),{ }^{5}$ solid-in-oil-in-water $(\mathrm{s} / \mathrm{o} / \mathrm{w}),{ }^{6-13}$ and solid-in-oil-in-oil (s/o/o). ${ }^{14,15} \mathrm{~A}$ w/o/w process is applied when a solvent evaporation technique is used to encapsulate protein or peptide drugs, whereby the active protein first needs to be dissolved in aqueous inner phase. However, use of protein or peptide drugs in aqueous solution results in the presence of a water/organic interface that might compromise the stability of the encapsulated protein or peptide drug. Further, permeation of emulsion droplets from inner water phase into outer water phase results in relatively low encapsulation efficiency (EE). To solve these problems, $\mathrm{s} / \mathrm{o} / \mathrm{w}$ or $\mathrm{s} / \mathrm{o} / \mathrm{o}$ methods have been used to encapsulate protein or peptide drugs, in which the drug powder is directly dispersed in organic phase, with subsequent addition of the suspension to outer water phase. ${ }^{21-27}$ Whichever s/o/o or $\mathrm{s} / \mathrm{o} / \mathrm{w}$ technique is used, it is essential to use a pretreatment to reduce the particle size of the protein or peptide drug in the powder to $1-10 \mu \mathrm{m}$ before the first s/o suspension step. Lyophilization of a water solution containing a protein or peptide drug with 
additives is widely performed. However, denaturing and aggregation of protein and peptide drugs is common during freezing and subsequent dehydration, even in the presence of lyoprotectors. Further, traditional s/o/w emulsions are generally emulsified using intense mechanical force generated by a homogenizer, which can damage the bioactivity of a protein or peptide drug. ${ }^{21-27}$ Also, such methods cannot address the problems in achieving sustained-release properties for all drugs, because different drugs have different physicochemical characteristics.

We have developed s/o/o/w and s/o/o/ethanol (e) emulsions for preparation of protein microspheres. ${ }^{16,17}$ However, a method for preparation of poly(lactic-co-glycolic acid) (PLGA) microspheres using a water-in-oil-in-hydrophilic oil-in-water $\left(\mathrm{w} / \mathrm{o} / \mathrm{o}_{\mathrm{h}} / \mathrm{w}\right)$ emulsion to achieve sustained-release drug delivery has not been developed as yet. Therefore, in this study, we developed a novel method for preparation of an emulsion to carry spherical-shaped drug-loaded microspheres for sustained drug release.

\section{Materials and methods Materials}

PLGA 3A dl (lactide to glycolide ratio 50:50, molecular weight 47,000), 2A dl (lactide to glycolide ratio 50:50, molecular weight 13,000), and polylactide (LPLA, molecular weight 60,000, low viscosity; HPLA, molecular weight 83,000, high viscosity) were obtained from Lakeshore Biopolymers Inc (Cincinnati, OH, USA). Poly(vinyl alcohol) (PVA, molecular weight 30,000-50,000, 87\%-89\% hydrolyzed) was purchased from Sigma (St Louis, MO, USA). Phosphate-buffered solution ( $\mathrm{pH}$ 7.2) and a micro bicinchoninic acid protein assay kit were sourced from Pierce (Rockford, IL, USA). Dichloromethane, polyethylene glycol (molecular weight 8000), ethylene glycol, 1,2-propylene glycol, glycerol, polyvinyl-pyrrolidone, poloxamer 188, and trehalose were obtained from the Sinopharm Chemical Reagent Co., Ltd (Shanghai, People's Republic of China). Bovine serum albumin was sourced from Siji Company (Shanghai, People's Republic of China). All chemicals were used without further purification.

\section{Preparation of protein-loaded} microspheres using the $\mathrm{w} / \mathrm{o} / \mathrm{o}_{\mathrm{h}} / \mathrm{w}$ method First, $1 \mathrm{~mL}$ of drug or water was dispersed in $5 \mathrm{~mL}$ of different concentrations of PLGA, PLA, and dichloromethane solutions by stirring at a rotation speed of $2500 \mathrm{rpm}$ for one minute using a homogenizer (FA25, Fluko, Shanghai, People's Republic of China). The mixture was then dispersed into hydrophilic oil phase (ethylene glycol to glycerol ratio 4:1; 1,2-propylene glycol to glycerol ratio 4:1) containing $1 \%$ w/w PVA and 5\% w/w $\mathrm{NaCl}$ water solution with agitation using an electromotive stirrer (JJ-1, Jintan Xinhang Co, Ltd, Jiangsu, People's Republic of China) equipped with twoplate shaft stirring at $1200 \mathrm{rpm}$ and $4^{\circ} \mathrm{C}$ for five minutes. Hydrophilic oil phase was used to extract the organic solvent from the oil phase and also to dissolve the aqueous phase and enhance solidification of the PLGA microspheres. The mixed emulsion was solidified in $5 \% \mathrm{NaCl}$ water solution with stirring continued at $200 \mathrm{rpm}$ for four hours to extract the organic solvent. The solid microspheres were collected by centrifugation (Anker TGL-16C, Ningbo Tianyu Optoelectronic Technology, Ningbo, People's Republic of China) at $2000 \mathrm{rpm}$, then washed three times with distilled water and freeze-dried using a lyophilizer (Christ Alpha 1-2, Martin Christ Gefriertrocknungsanlagen GmbH, Osterode am Harz, Germany) at $40^{\circ} \mathrm{C}$ for 24 hours.

\section{Scanning electron and optical microscopy}

A scanning electron microscope (SEM, Sirion, Hillsboro, OR, USA) was used to obtain electron microscopic images of the microspheres, and an optical microscope (CX-41, Olympus, Tokyo, Japan) was used to obtain optical images. The microspheres were attached to double-edged conductive tape attached to the SEM specimen holders. The microspheres were then coated with a layer of gold by spraying of gold vapor for 10 minutes under an argon atmosphere, with images recorded at a sputtering energy of $5 \mathrm{kV}$ under high vacuum.

\section{Size distribution of microspheres}

The mean particle size and size distribution of the microspheres were measured using a particle size and shape analyzer (CIS-100, Ankersmid, Nijverda, The Netherlands) with a laser wavelength of $633 \mathrm{~nm}$. The microspheres to be measured were suspended in the quartz sample holder filled with isopropyl alcohol and subjected to magnetic stirring.

\section{Size exclusion high-performance liquid chromatography}

A size exclusion high-performance liquid chromatography (SEC-HPLC) assay was carried out using an HPLC system equipped with a TSK G2000Sk-XL1 column (Younglin, Kyounggi-do, Republic of Korea). The mobile phase comprised $0.15 \mathrm{M}$ sodium chloride and $50 \mathrm{mM}$ sodium phosphate ( $\mathrm{pH} 7.25$ ), and chromatographic charts were recorded at an 
ultraviolet detection wavelength of $214 \mathrm{~nm}$. Next, $100 \mu \mathrm{L}$ of each sample of dissolved protein was filtered using a $0.22 \mu \mathrm{m}$ filter (Millipore, Billerica, MA, USA) and injected into the HPLC system at a mobile phase flow rate of $1.0 \mathrm{~mL}$ per minute. The amounts of native protein monomers and aggregates present were calculated from the monomer and aggregate peaks, respectively. The results are expressed as peak percentages of the total area.

\section{Micro bicinchoninic acid and $\beta$-galactosidase activity assays}

The concentration of the protein samples was determined using a micro bicinchoninic acid protein kit. To examine how the bioactivity of proteins could be preserved during the PLGA microsphere preparation process, $\beta$-galactosidase, a protein with a quaternary structure and molecular weight of over $500 \mathrm{kDa}$, was loaded into the system and recovered at each step for assay of activity. Trehalose $1 \%(\mathrm{w} / \mathrm{w})$ as the mass of dextran was added to the solution for lyoprotection. The bioactivity of the recovered protein was assayed by hydrolysis of o-nitrophenyl-b-D-galactopyranoside (the substrate), which generated a colored product absorbing photons at $410 \mathrm{~nm}$.

\section{In vitro release test}

The in vitro release kinetics of the microspheres were investigated in phosphate-buffered solution $(\mathrm{pH} 7.2)$ at $37^{\circ} \mathrm{C}$. First, $25 \mathrm{mg}$ of microspheres was suspended in a $5 \mathrm{~mL}$ test tube containing $2 \mathrm{~mL}$ of phosphate-buffered solution. The sample tubes were then placed in an incubator (KYC 100C, Shanghai Fuma Laboratory Equipment, Shanghai, People's Republic of China) and shaken horizontally at $110 \mathrm{rpm}$. At a preset time following incubation, the microspheres were retrieved from the solution by centrifugation at $1000 \mathrm{rpm}$ and $4{ }^{\circ} \mathrm{C}$. The supernatant release medium was withdrawn and replaced with fresh phosphate-buffered solution each day, with determination of the protein concentration using a micro bicinchoninic acid assay kit. ${ }^{7-13,16-18}$

\section{Results and discussion Characterization of composite microspheres}

Figures 1 and 2 show optical microscopic images of the composite microspheres. Figure 1 shows the free solidified microspheres and Figure 2 shows hardened freeze-dried microspheres which differed in their transmittance. Figure 3 is an SEM image of the microspheres, showing smooth surfaces and small holes, possibly because the organic
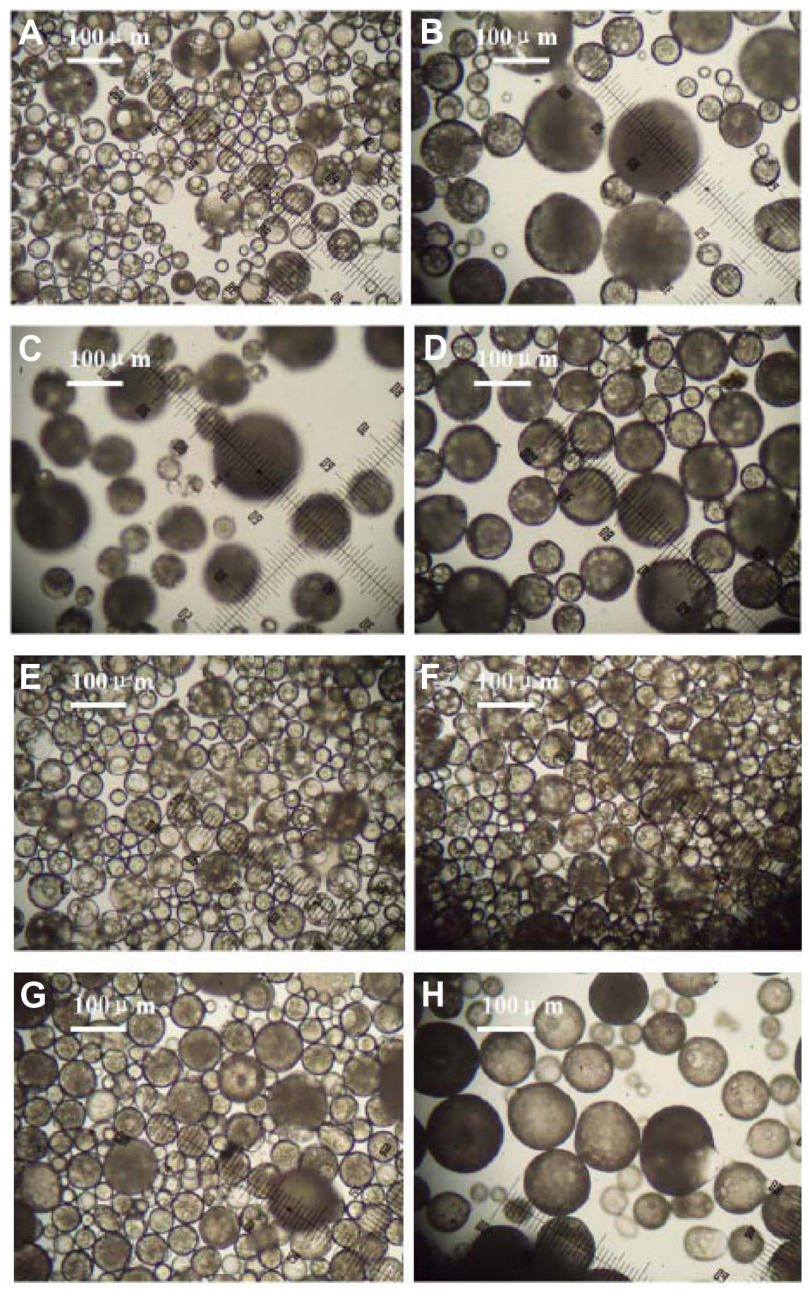

Figure I Optical microscopic images of free solidified microspheres. (A) PLGA (3A50/50), (B) PLGA (3A50/50)/LPLA = 40/80, (C) PLGA (3A50/50)/HPLA = 40/60, (D) PLGA (3A50/50)/HPLA $=40 / 80$, (E) PLGA (2A50/50)/HPLA $=40 / 80$, and (F) PLGA (2A50/50)/LPLA $=40 / 80 . \mathrm{W}_{1}, 5 \% \mathrm{w} / \mathrm{w} \mathrm{BSA}$ and dextran (BSA to dextran ratio $6 \mathrm{mg}: 6 \mathrm{mg})$ water cosolution; $\mathrm{O}_{\mathrm{h}}, \mathrm{PG} / \mathrm{G}=4(5.5 \mathrm{~mL}$ containing $0.5 \mathrm{~mL}$ of I\% PVA and $5 \% \mathrm{NaCl}) ; \mathrm{W}_{2}, 5 \% \mathrm{NaCl} 1000 \mathrm{~mL}$; oil phase $10 \%, 1200 \mathrm{mg}$ of dichloromethane solvent. (G) PLGA (3A50/50)/LPLA $=40 / 80$ and (H) PLGA (3A50/50)/HPLA $=40 / 80$. $\mathrm{W}_{1}, 5 \% \mathrm{w} / \mathrm{w}$ BSA and dextran (BSA to dextran ratio $6 \mathrm{mg}: 6 \mathrm{mg}$ ) water solution; $\mathrm{O}_{\mathrm{h}}$, $D E G / G=4(5.5 \mathrm{~mL}$ containing $0.5 \mathrm{~mL}$ of $1 \%$ PVA and $5 \% \mathrm{NaCl}) ; \mathrm{W}_{2}, 5 \% \mathrm{NaCl}$ $1000 \mathrm{~mL}$; oil phase 10\%, $1200 \mathrm{mg}$ of dichloromethane solvent.

Abbreviations: BSA, bovine serum albumin; PLGA, poly(lactic-co-glycolic acid); LPLA, low viscosity polylactide (molecular weight 60,000); HPLA, high viscosity polylactide (molecular weight 83,000); PVA, poly(vinyl alcohol); PG/G, I, 2-propylene glycol/glycerol; $\mathrm{O}_{\mathrm{h}}$, hydrophilic oil; DEG/G, ethylene glycol/glycerol; $\mathrm{NaCl}$, sodium chloride; $\mathrm{W}_{1}, 1 \%$ PVA and $5 \% \mathrm{NaCl}$ water solution; $\mathrm{W}_{2}, 5 \% \mathrm{NaCl}$ water solution; $w / w$, trehalose $1 \%$

solvent was extracted rapidly from the inner layers of the PLGA microspheres. Figure 4 is an optical microscopic image of the microparticles and Figure 5 is an SEM image of the recovered microspheres, showing that encapsulation of bovine serum albumin and dextran water solution into the microspheres formed freely aggregated microparticles $1-5 \mu \mathrm{m}$ in size. This was possibly because bovine serum albumin and dextran led to freezing-induced phase separation and self-formed microparticles during freeze-drying. ${ }^{18-20}$ 

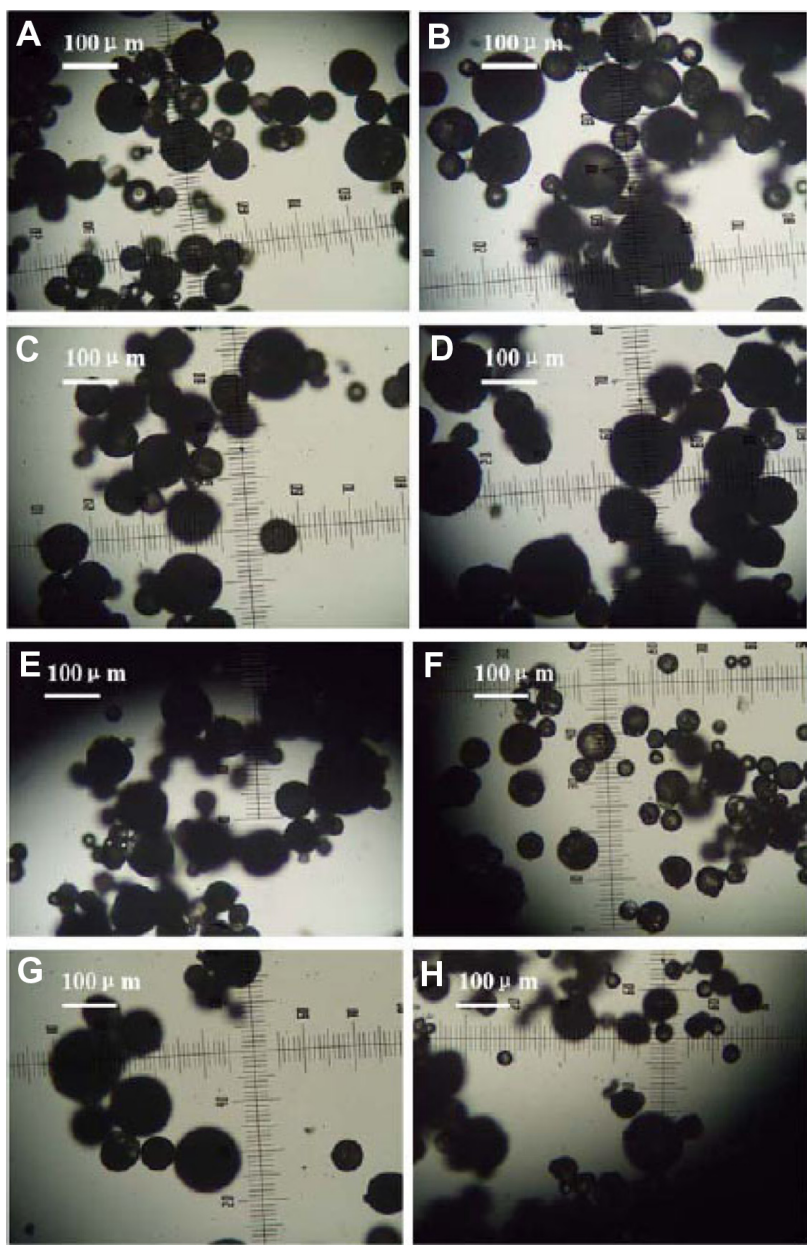

Figure 2 Optical microscopic images of solidified microspheres. $W_{1}, 5 \% \mathrm{w} / \mathrm{w} \mathrm{BSA}$ and dextran (BSA to dextran ratio $6 \mathrm{mg}: 6 \mathrm{mg}$ ) water solution; $\mathrm{O}, \mathrm{DEG} / \mathrm{G}=4$ (5.5 mL containing $0.5 \mathrm{~mL}$ of $1 \%$ PVA and $5 \% \mathrm{NaCl}$ ); $\mathrm{W}_{2}, 5 \% \mathrm{NaCl} 1000 \mathrm{~mL}$; oil phase, $10 \%$ of $1200 \mathrm{mg}$ dichloromethane solvent. (A) PLGA (3A50/50), (B) PLGA $(3 \mathrm{~A} 50 / 50) / \mathrm{LPLA}=40 / 80$, (C) PLGA (3A50/50)/HPLA = 40/60, (D) PLGA (3A50/50)/ HPLA = 40/80; (E) PLGA (2A50/50)/HPLA = 40/80, and (F) PLGA $(2 A 50 / 50) /$ $\mathrm{LPLA}=40 / 80 . \mathrm{W}_{1}, 5 \% \mathrm{w} / \mathrm{w} \mathrm{BSA}$ and dextran (BSA to dextran ratio $6 \mathrm{mg}: 6 \mathrm{mg}$ ) water cosolution; $\mathrm{O}_{\mathrm{h}}, \mathrm{PG} / \mathrm{G}=4(5.5 \mathrm{~mL}$ containing $0.5 \mathrm{~mL}$ of $\mathrm{I} \% \mathrm{PVA}$ and $5 \% \mathrm{NaCl})$; $W_{2}, 5 \% \mathrm{NaCl} 1000 \mathrm{~mL}$; oil phase $10 \%, 1200 \mathrm{mg}$ of dichloromethane solvent. (G) PLGA (3A50/50)/LPLA = 40/80 and (H) PLGA (3A50/50)/HPLA = 40/80. Abbreviations: BSA, bovine serum albumin; PLGA, poly(lactic-co-glycolic acid); LPLA, low viscosity polylactide (molecular weight 60,000); HPLA, high viscosity polylactide (molecular weight 83,000); PVA, poly(vinyl alcohol); PG/G, I, 2-propylene glycol/glycerol; $\mathrm{O}_{\mathrm{h}}$, hydrophilic oil; $\mathrm{DEG} / \mathrm{G}$, ethylene glycol/glycerol; $\mathrm{NaCl}$, sodium chloride; $\mathrm{W}_{1}, 1 \% \mathrm{PVA}$ and $5 \% \mathrm{NaCl}$ water solution; $\mathrm{W}_{2}, 5 \% \mathrm{NaCl}$ water solution; $\mathrm{w} / \mathrm{w}$, trehalose $1 \%$.
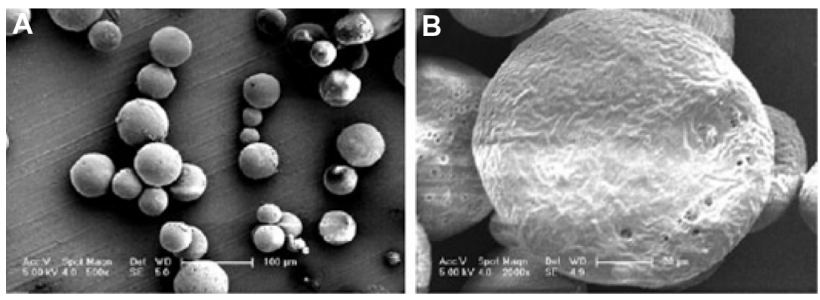

Figure 3 Scanning electron micrographs of microspheres prepared using PLGA (3A50/50) (A), and PLGA (3A50/50)/HPLA (B). $W_{1}, 5 \%$ w/w BSA and dextran (BSA to dextran ratio $6 \mathrm{mg}: 6 \mathrm{mg})$ water solution; $\mathrm{O}_{\text {h }}$ DEG/G $=4(5.5 \mathrm{~mL}$ containing $0.5 \mathrm{~mL}$ of $1 \%$ PVA and $5 \% \mathrm{NaCl}$ ); $\mathrm{W}_{2}, 5 \% \mathrm{NaCl} 1000 \mathrm{~mL}$; oil phase $10 \%$, PLGA (3A50/50)/HPLA $=40 / 80,1200 \mathrm{mg}$ of dichloromethane solvent.

Abbreviations: BSA, bovine serum albumin; PLGA, poly(lactic-co-glycolic acid); HPLA, high viscosity polylactide (molecular weight 83,000 ); PVA, poly(vinyl alcohol).
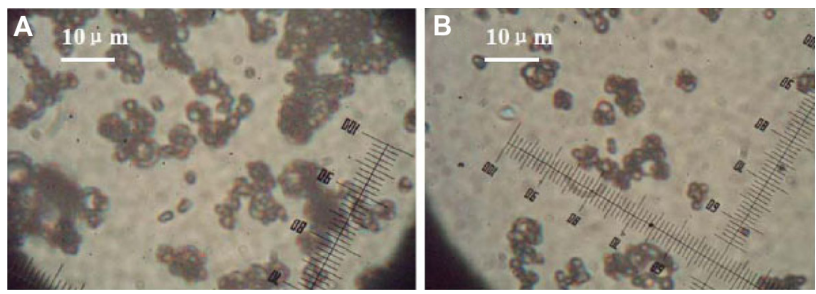

Figure 4 Optical microscopic images of protein dextran microparticles recovered from microspheres. (A) $\mathrm{W}_{1}, 5 \% \mathrm{w} / \mathrm{w}$ BSA and dextran (BSA to dextran ratio $6 \mathrm{mg}: 6 \mathrm{mg})$ water solution; $\mathrm{O}_{\mathrm{h}}$, DEG/G $=4(5.5 \mathrm{~mL}$ containing $0.5 \mathrm{~mL}$ of I\% PVA and $5 \% \mathrm{NaCl}) ; \mathrm{W}_{2}, 5 \% \mathrm{NaCl} 1000 \mathrm{~mL}$; oil phase 10\%, PLGA (3A50/50)/LPLA = 40/80; $1200 \mathrm{mg}$ of dichloromethane solvent; (B) $\mathrm{W}_{1}, 5 \% \mathrm{w} / \mathrm{w}$ BSA and dextran (BSA to dextran ratio $6 \mathrm{mg}: 6 \mathrm{mg})$ water solution; $\mathrm{O}_{h}, \mathrm{PG} / \mathrm{G}=4(5.5 \mathrm{~mL}$ containing $0.5 \mathrm{~mL}$ of I\% PVA and $5 \% \mathrm{NaCl}) ; \mathrm{W}_{2}, 5 \% \mathrm{NaCl} 1000 \mathrm{~mL}$; oil phase, I0\% PLGA (3A50/50)/ $\mathrm{LPLA}=40 / 80,1200 \mathrm{mg}$ of dichloromethane solvent.

Abbreviations: BSA, bovine serum albumin; PLGA, poly(lactic-co-glycolic acid); LPLA, low viscosity polylactide (molecular weight 60,000); PG/G, I, 2-propylene glycol/glycerol; $\mathrm{O}_{h}$, hydrophilic oil; $\mathrm{DEG} / \mathrm{G}$, ethylene glycol/glycerol; $\mathrm{NaCl}$, sodium chloride; $\mathrm{W}_{1}, 1 \% \mathrm{PVA}$ and $5 \% \mathrm{NaCl}$ water solution; $\mathrm{W}_{2}, 5 \% \mathrm{NaCl}$ water solution; $w / w$, trehalose $1 \%$.

These microspheres were spherical in shape with diameters in the range of $20-100 \mu \mathrm{m}$ (Figure 6).

\section{Encapsulation efficiency}

Effect of viscosity of materials

Table 1 shows a significant discrepancy in EE between LPLA and HPLA formed using the $\mathrm{w} / \mathrm{o} / \mathrm{o}_{\mathrm{h}} / \mathrm{w}$ method. The EE of composite LPLA microspheres was significantly higher than that of the HPLA microspheres. This is possibly because the HPLA was more hydrophobic than the LPLA, and bovine serum albumin was hydrophilic whereas protein and dextran were also hydrophilic and more easily adsorbed onto the hydrophilic LPLA.

\section{Effect of hydrophobic properties of materials}

Table 2 shows a significant discrepancy in EE between PLGA 2A and PLGA 3A when the w/o/o $/ \mathrm{h}$ wethod was used. The

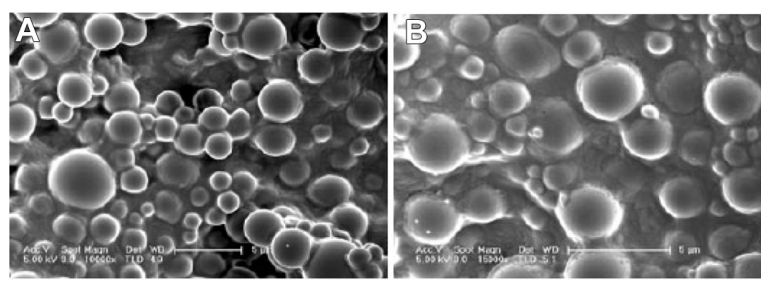

Figure 5 Scanning electron micrographs of protein dextran recovered from microspheres. (A) $\mathrm{W}_{1}, 5 \% \mathrm{w} / \mathrm{w}$ BSA and dextran (BSA to dextran ratio $6 \mathrm{mg}: 6 \mathrm{mg}$ ) water solution; $\mathrm{O}_{\mathrm{h}}, \mathrm{DEG} / \mathrm{G}=4(5.5 \mathrm{~mL}$ containing $0.5 \mathrm{~mL}$ of $1 \% \mathrm{PVA}$ and $5 \% \mathrm{NaCl})$; $\mathrm{W}_{2}, 5 \% \mathrm{NaCl} 1000 \mathrm{~mL}$; oil phase 10\%; PLGA (3A50/50)/LPLA = 40/80, $1200 \mathrm{mg}$ of dichloromethane solvent. (B) $\mathrm{W}_{1}, 5 \% \mathrm{w} / \mathrm{w}$ BSA and dextran (BSA to dextran ratio $6 \mathrm{mg}: 6 \mathrm{mg})$ water solution; $\mathrm{O}_{\mathrm{h}}, \mathrm{PG} / \mathrm{G}=4(5.5 \mathrm{~mL}$ containing $0.5 \mathrm{~mL}$ of $1 \% \mathrm{PVA}$ and $5 \% \mathrm{NaCl}) ; \mathrm{W}_{2}, 5 \% \mathrm{NaCl} 1000 \mathrm{~mL}$, oil phase 10\%; PLGA (3A50/50)/LPLA = 40/80, $1200 \mathrm{mg}$ of dichloromethane solvent.

Abbreviations: BSA, bovine serum albumin; PLGA, poly(lactic-co-glycolic acid); LPLA, low viscosity polylactide (molecular weight 60,000); PVA, poly(vinyl alcohol); PG/G, I, 2-propylene glycol/glycerol; $O_{h}$, hydrophilic oil; DEG/G, ethylene glycol/ glycerol; $\mathrm{NaCl}$, sodium chloride; $\mathrm{W}_{1}, 1 \% \mathrm{PVA}$ and $5 \% \mathrm{NaCl}$ water solution; $\mathrm{W}_{2}, 5 \%$ $\mathrm{NaCl}$ water solution; $\mathrm{w} / \mathrm{w}$, trehalose $1 \%$. 


\section{Volume density graph (full scale)}

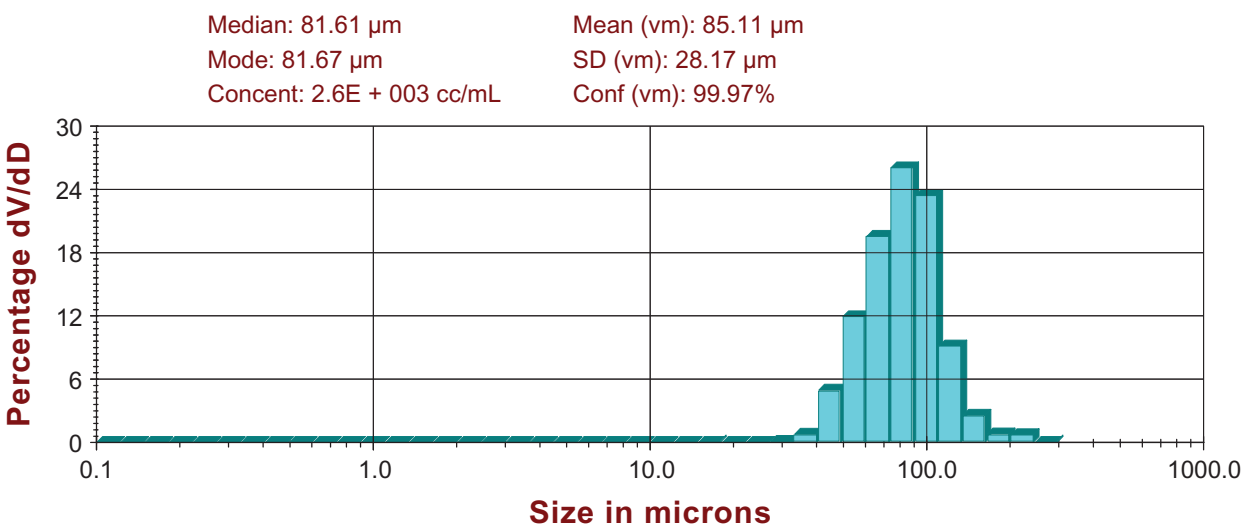

Figure 6 Distribution of microspheres. $\mathrm{W}_{1}, 5 \% \mathrm{w} / \mathrm{w}$ BSA and dextran (BSA to dextran ratio $6 \mathrm{mg}: 6 \mathrm{mg}$ ) water solution; $\mathrm{O}$, PG/G = 4 (5.5 mL containing $0.5 \mathrm{~mL}$ of I\% PVA and $5 \% \mathrm{NaCl}) ; \mathrm{W}_{2}, 5 \% \mathrm{NaCl} 1000 \mathrm{~mL}$, oil phase 10\%; PLGA (3A50/50)/LPLA = 40/80, $1200 \mathrm{mg}$ of dichloromethane solvent.

Abbreviations: BSA, bovine serum albumin; PLGA, poly(lactic-co-glycolic acid); LPLA, low viscosity polylactide (molecular weight 60,000); PVA, poly(vinyl alcohol); PG/G, I, 2-propylene glycol/glycerol; $\mathrm{O}_{\mathrm{h}}$, hydrophilic oil; $\mathrm{NaCl}$, sodium chloride; $\mathrm{W}_{1}, 1 \% \mathrm{PVA}$ and $5 \% \mathrm{NaCl}$ water solution; $\mathrm{W}_{2}, 5 \% \mathrm{NaCl}$ water solution; w/w, trehalose $1 \%$; $\mathrm{dV}$ / $\mathrm{dD}$, d volume/d density; SD, standard deviation.

EE of the composite PLGA 2A microspheres was significantly higher than that of the PLGA $3 \mathrm{~A}$ microspheres. This is possibly because PLGA 3A was more hydrophobic than PLGA 2A, while bovine serum albumin was hydrophilic.

\section{Effect of ratio of PLGA $3 A$ to HPLA}

Table 3 shows a significant discrepancy in EE according to the PLGA 3A and HPLA ratio when the $\mathrm{w} / \mathrm{o} / \mathrm{o}_{\mathrm{h}} / \mathrm{w}$ method was used. The EE of the high ratio PLGA $3 \mathrm{~A}$ and HPLA microspheres was significantly higher than that of low ratio PLGA 3A microspheres. This may be because the high ratio PLGA 3A materials were more hydrophilic than the low ratio PLGA $3 \mathrm{~A}$ materials, while bovine serum albumin was hydrophilic.

\section{Effect of hydrophilic oil phase}

Table 4 shows a significant discrepancy in EE between the hydrophilic oil phase of the ethylene glycol and glycerol

Table I Effect of PLGA/PLA ratio on loading efficiency and encapsulation efficiency $(n=3)$

\begin{tabular}{lll}
\hline Formulation & $\begin{array}{l}\text { Loading } \\
\text { efficiency } \\
\text { (\% } \pm \text { SD) }\end{array}$ & $\begin{array}{l}\text { Encapsulation } \\
\text { efficiency } \\
\text { (\% } \pm \text { SD) }\end{array}$ \\
\hline (A) PLGA3A & $1.41 \pm 0.09$ & $31.04 \pm 1.98$ \\
(B) PLGA3A:LPLA & $1.39 \pm 0.19$ & $30.58 \pm 4.18$ \\
(C) PLGA3A:HPLA & $0.96 \pm 0.09$ & $19.58 \pm 1.98$ \\
\hline
\end{tabular}

Notes: $\mathrm{W}_{1}, 5 \% \mathrm{w} / \mathrm{w}$ BSA and dextran (BSA to dextran ratio $6 \mathrm{mg}: 6 \mathrm{mg}$ ) water solution; $\mathrm{O}_{\mathrm{h}}, \mathrm{DEG} / \mathrm{G}=4(5.5 \mathrm{~mL}$ containing $0.5 \mathrm{~mL}$ of $1 \% \mathrm{PVA}$ and $5 \% \mathrm{NaCl}) ; \mathrm{W}_{2}$, $5 \% \mathrm{NaCl} 1000 \mathrm{~mL}$; oil phase $10 \%, 1200 \mathrm{mg}$ of dichloromethane solvent. (A) PLGA (3A50/50), (B) PLGA (3A50/50)/LPLA 40/80, and (C) PLGA (3A50/50)/HPLA 40/80. Abbreviations: BSA, bovine serum albumin; PLGA, poly(lactic-co-glycolic acid); LPLA, low viscosity polylactide (molecular weight 60,000); HPLA, high viscosity polylactide (molecular weight 83,000); PG/G, I, 2-propylene glycol/glycerol; $O_{h}$, hydrophilic oil; $\mathrm{DEG} / \mathrm{G}$, ethylene glycol/glycerol; $\mathrm{NaCl}$, sodium chloride; $\mathrm{W}_{1}, 1 \% \mathrm{PVA}$ and $5 \% \mathrm{NaCl}$ water solution; $\mathrm{W}_{2}, 5 \% \mathrm{NaCl}$ water solution; w/w, trehalose I\%; PVA, poly(vinyl alcohol); PLA, polylactide; $\mathrm{SD}$, standard deviation. mixture and the hydrophilic oil phase of the 1,2-propylene glycol and glycerol mixture using the $\mathrm{w} / \mathrm{o} / \mathrm{o}_{\mathrm{h}} / \mathrm{w}$ method. The EE of the composite microspheres was significantly higher when using the hydrophilic oil phase of the ethylene glycol and glycerol microspheres. This could be because ethylene glycol was more hydrophilic than 1,2-propylene glycol, while bovine serum albumin was hydrophilic.

\section{Integrity of proteins at each formulation step}

In this study, protein aggregation after each microencapsulation step was assayed for myoglobin and bovine serum albumin using SEC-HPLC. The results are shown in Table 5. The amounts of aggregated myoglobin and bovine serum albumin were observed before and after each of the formulation steps.

Table 2 Effect of PLGA to PLA ratio on loading and encapsulation efficiency $(n=3)$

\begin{tabular}{lll}
\hline Formulation & $\begin{array}{l}\text { Loading } \\
\text { efficiency } \\
(\% \pm \text { SD) }\end{array}$ & $\begin{array}{l}\text { Encapsulation } \\
\text { efficiency } \\
(\% \pm \text { SD) }\end{array}$ \\
\hline (I) PLGA2A:HPLA $=40: 80$ & $1.68 \pm 0.11$ & $39.96 \pm 2.18$ \\
(II) PLGA2A:LPLA $=40: 80$ & $2.01 \pm 0.13$ & $44.22 \pm 2.84$ \\
(III) PLGA3A:LPLA $=40: 80$ & $1.39 \pm 0.19$ & $30.58 \pm 4.18$ \\
(IV) PLGA3A:HPLA $=40: 80$ & $0.96 \pm 0.09$ & $19.58 \pm 1.98$ \\
\hline
\end{tabular}

Notes: $\mathrm{W}_{1}, 5 \% \mathrm{w} / \mathrm{w}$ BSA and dextran (BSA to dextran ratio $6 \mathrm{mg}: 6 \mathrm{mg}$ ) water solution; $\mathrm{O}_{\mathrm{h}}, \mathrm{DEG} / \mathrm{G}=4(5.5 \mathrm{~mL}$ containing $0.5 \mathrm{~mL}$ of $1 \% \mathrm{PVA}$ and $5 \% \mathrm{NaCl}) ; \mathrm{W}_{2}$, $5 \% \mathrm{NaCl} 1000 \mathrm{~mL}$; oil phase $10 \%, 1200 \mathrm{mg}$ of dichloromethane solvent. Formulation (I), PLGA (2A50/50)/LPLA = 40/80; formulation (II), PLGA (2A50/50)/HPLA = 40/80; formulation (III) PLGA (3A50/50)/LPLA = 40/80; formulation (IV), PLGA (3A50/50)/ HPLA $=40 / 80$.

Abbreviations: BSA, bovine serum albumin; PLGA, poly(lactic-co-glycolic acid); LPLA, low viscosity polylactide (molecular weight 60,000 ); HPLA, high viscosity polylactide (molecular weight 83,000); $\mathrm{O}_{\mathrm{h}}$, hydrophilic oil; DEG/G, ethylene glycol/ glycerol; $\mathrm{NaCl}$, sodium chloride; $\mathrm{W}_{1}, 1 \% \mathrm{PVA}$ and $5 \% \mathrm{NaCl}$ water solution; $\mathrm{W}_{2}, 5 \%$ $\mathrm{NaCl}$ water solution; w/w, trehalose I\%; PVA, poly(vinyl alcohol); PLA, polylactide; $\mathrm{SD}$, standard deviation. 
Table 3 Effect of PLGA to PLA ratio on loading and encapsulation efficiency $(n=3)$

\begin{tabular}{lll}
\hline Formulation & $\begin{array}{l}\text { Loading } \\
\text { efficiency } \\
\text { (\% } \pm \text { SD) }\end{array}$ & $\begin{array}{l}\text { Encapsulation } \\
\text { efficiency } \\
\text { (\% } \pm \text { SD) }\end{array}$ \\
\hline (I) PLGA3A:HPLA $=40: 60$ & $1.17 \pm 0.22$ & $25.74 \pm 4.84$ \\
(II) PLGA3A:HPLA $=40: 80$ & $0.96 \pm 0.09$ & $19.58 \pm 1.98$ \\
\hline
\end{tabular}

Notes: $\mathrm{W}_{1}, 5 \% \mathrm{w} / \mathrm{w}$ BSA and dextran (BSA to dextran ratio $6 \mathrm{mg}: 6 \mathrm{mg}$ ) water solution; $\mathrm{O}_{\mathrm{h}}, \mathrm{DEG} / \mathrm{G}=4(5.5 \mathrm{~mL}$ containing $0.5 \mathrm{~mL}$ of $1 \% \mathrm{PVA}$ and $5 \% \mathrm{NaCl})$; $\mathrm{W}_{2}, 5 \% \mathrm{NaCl} 1000 \mathrm{~mL}$; oil phase $10 \%, 1200 \mathrm{mg}$ of dichloromethane solvent; formulation (I) PLGA (3A50/50)/HPLA = 40/60; formulation (II) PLGA (3A50/50)/ HPLA $=40 / 80$.

Abbreviations: BSA, bovine serum albumin; PLGA, poly(lactic-co-glycolic acid); LPLA, low viscosity polylactide (molecular weight 60,000 ); HPLA, high viscosity polylactide (molecular weight 83,000 ); PVA, poly(vinyl alcohol); $\mathrm{O}$, hydrophilic oil; DEG/G, ethylene glycol/glycerol; $\mathrm{NaCl}$, sodium chloride; $\mathrm{W}_{1}, 1 \% \mathrm{PVA}$ and $5 \% \mathrm{NaCl}$ water solution; $\mathrm{W}_{2}, 5 \% \mathrm{NaCl}$ water solution; $\mathrm{w} / \mathrm{w}$, trehalose I\%; PLA, polylactide; $\mathrm{SD}$, standard deviation.

Table 4 Effect of different $O_{h}$ on loading efficiency and encapsulation efficiency $(n=3)$

\begin{tabular}{lll}
\hline Formulation & $\begin{array}{l}\text { Loading efficiency } \\
(\% \pm \text { SD) }\end{array}$ & $\begin{array}{l}\text { Encapsulation efficiency } \\
(\% \pm \text { SD) }\end{array}$ \\
\hline A & $0.83 \pm 0.12$ & $18.26 \pm 2.64$ \\
B & $1.32 \pm 0.22$ & $29.04 \pm 4.84$ \\
C & $0.96 \pm 0.09$ & $21.12 \pm 1.98$ \\
D & $1.39 \pm 0.19$ & $30.58 \pm 4.18$ \\
\hline
\end{tabular}

Notes: $W_{1}, 5 \% \mathrm{w} / \mathrm{w}$ BSA and dextran (BSA to dextran ratio $6 \mathrm{mg}: 6 \mathrm{mg}$ ) water solution; $\mathrm{O}_{h}, \mathrm{PG} / \mathrm{G}=4$ (5.5 mL containing $0.5 \mathrm{~mL}$ of I\% PVA and $\left.5 \% \mathrm{NaCl}\right) ; \mathrm{W}_{2}, 5 \%$ $\mathrm{NaCl} 1000 \mathrm{~mL}$; oil phase $10 \%, 1200 \mathrm{mg}$ of dichloromethane solvent. Formulation $\mathrm{A}$, PLGA (3A50/50)/LPLA = 40/80; formulation B, PLGA (3A50/50)/HPLA = 40/80.

Abbreviations: BSA, bovine serum albumin; PLGA, poly(lactic-co-glycolic acid); LPLA, low viscosity polylactide (molecular weight 60,000); HPLA, high viscosity polylactide (molecular weight 83,000); PVA, poly(vinyl alcohol); PG/G, I, 2-propylene glycol/glycerol; $\mathrm{O}_{h}$, hydrophilic oil; DEG/G, ethylene glycol/glycerol; $\mathrm{NaCl}$, sodium chloride; $\mathrm{W}_{1}, 1 \% \mathrm{PVA}$ and $5 \% \mathrm{NaCl}$ water solution; $\mathrm{W}_{2}, 5 \% \mathrm{NaCl}$ water solution; $\mathrm{w} / \mathrm{w}$, trehalose $1 \%$; SD, standard deviation.

There was no significant decrease in the amount of protein monomer observed after each formulation step (lyophilization followed by washing with dichloromethane and microencapsulation into PLGA microspheres followed by recovery).
Table 5 Amount of myoglobin and BSA protein aggregated before and after each formulation step $(n=5)$

\begin{tabular}{ll}
\hline & $\begin{array}{l}\text { Aggregated } \\
\text { protein }(\% \pm \text { SD) }\end{array}$ \\
\hline Original BSA & $12.12 \pm 1.12$ \\
Original myoglobin & $10.09 \pm 1.59$ \\
BSA from microspheres & $11.90 \pm 2.02$ \\
Myoglobin from microspheres & $10.39 \pm 0.99$ \\
\hline
\end{tabular}

Abbreviations: BSA, bovine serum albumin; SD, standard deviation.

\section{Protein activity during formulation steps}

With regard to protein activity during the formulation steps, the EE of $\beta$-galactosidase was $85.1 \% \pm 1.2 \%$ by the $\mathrm{w} / \mathrm{o} / \mathrm{o}_{\mathrm{h}} / \mathrm{w}$ method and $60.2 \% \pm 4.3 \%$ by w/o/w. Figure 7 compares the activity recovery rate between proteins from microspheres prepared using the conventional w/o/w method and those prepared using the novel $\mathrm{w} / \mathrm{o} / \mathrm{o}_{\mathrm{h}} / \mathrm{w}$ method. For protein protected using the abovementioned novel method of microencapsulation, more than $78 \%(w / w)$ of $\beta$-galactosidase activity was preserved, while for protein protected using the $\mathrm{w} / \mathrm{o} / \mathrm{w}$ method, the recovery rate was $40 \%(\mathrm{w} / \mathrm{w})$.

\section{In vitro release study}

\section{Effect of material viscosity}

Figure 8 shows that the burst release decreased and incomplete release increased in the order of PLGA, LPLA, and HPLA. This may be because the rate of material degradation decreased in the same order of PLGA, LPLA, and HPLA.

\section{Effect of hydrophobic properties of materials}

Figure 9 shows that the burst release decreased and incomplete release increased in the order of PLGA 2A, PLGA 3A, LPLA, and HPLA. This may be because the rate of material degradation decreased in this order.

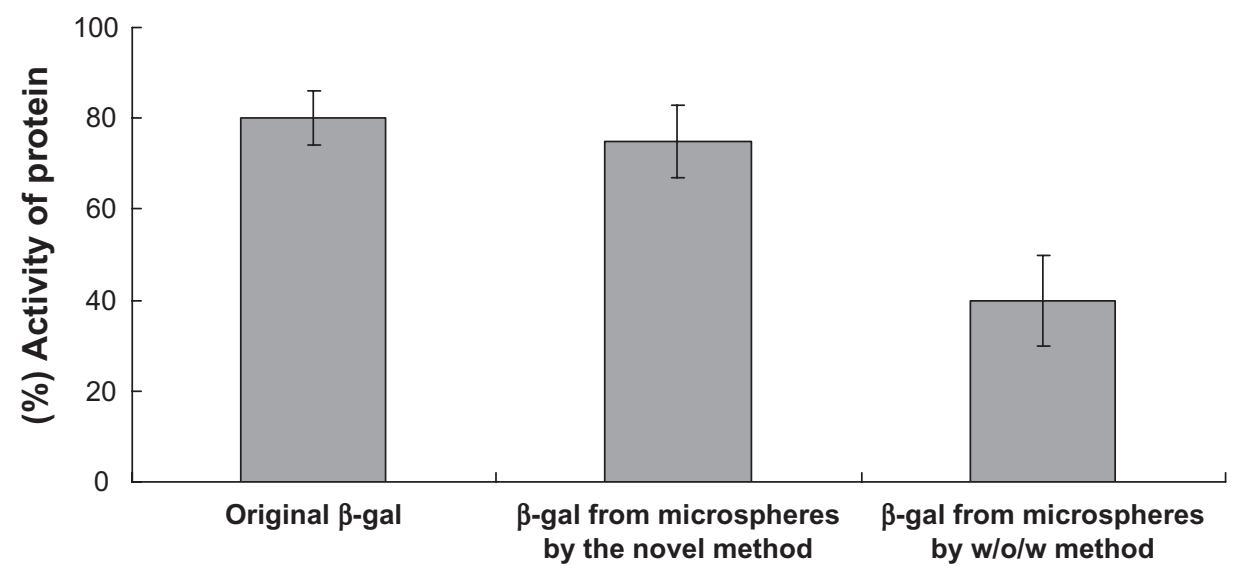

Figure 7 Comparison of recovery rates for protein activity from microspheres prepared using the different methods $(n=3)$. Abbreviation: $\beta$-gal, $\beta$-galactosidase; w/o/w, water-in-oil-in-water. 


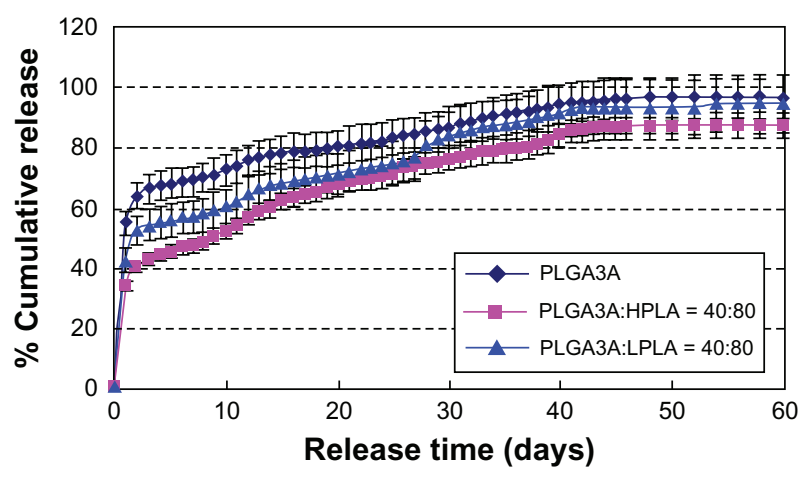

Figure 8 Effect of ratio of PLGA/PLA on release in vitro $(n=3) . W_{1}, 5 \%$ w/w $\mathrm{BSA}$ and dextran (BSA to dextran ratio $6 \mathrm{mg}: 6 \mathrm{mg}$ ) water solution; $\mathrm{O}_{\mathrm{h}}$, DEG/G $=4$ (5.5 mL containing $0.5 \mathrm{~mL}$ of I\% PVA and $5 \% \mathrm{NaCl}$ ); $\mathrm{W}_{2}, 5 \% \mathrm{NaCl} 1000 \mathrm{~mL}$, oil phase 10\%, $1200 \mathrm{mg}$ of dichloromethane solvent. (A) PLGA (3A50/50), (B) PLGA $(3 A 50 / 50) / L P L A=40 / 80$, and $(C)$ PLGA $(3 A 50 / 50) / H P L A=40 / 80$.

Abbreviations: BSA, bovine serum albumin; PLGA, poly(lactic-co-glycolic acid); LPLA, low viscosity polylactide (molecular weight 60,000); HPLA, high viscosity polylactide (molecular weight 83,000); PVA, poly(vinyl alcohol); PG/G, I, 2-propylene glycol/glycerol; $\mathrm{O}_{\mathrm{h}}$, hydrophilic oil; $\mathrm{DEG} / \mathrm{G}$, ethylene glycol/glycerol; $\mathrm{NaCl}$, sodium chloride; $\mathrm{W}_{1}, 1 \% \mathrm{PVA}$ and $5 \% \mathrm{NaCl}$ water solution; $\mathrm{W}_{2}, 5 \% \mathrm{NaCl}$ water solution; $w / w$, trehalose I\%; PLA, polylactide.

\section{Effect of PLGA $3 A$ and HPLA ratio}

Figure 10 shows that the burst release decreased and incomplete release increased in the order of high ratio PLGA 3A then low ratio PLGA 3A. This was possibly because the rate of material degradation decreased in the same order.

\section{Effect of hydrophilic oil phase}

Figure 11 shows that the burst release decreased and incomplete release increased in the order of ethylene glycol then 1,2-propylene glycol because of their different hydrophilic properties.

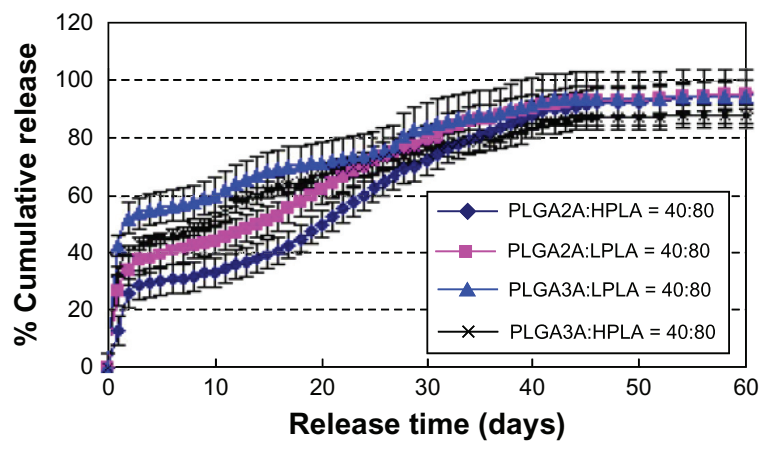

Figure 9 Effect of different materials on release in vitro. $W_{1}, 5 \% \mathrm{w} / \mathrm{w} \mathrm{BSA}$ and dextran (BSA to dextran ratio $6 \mathrm{mg}: 6 \mathrm{mg}$ ) water solution; $\mathrm{O}_{\mathrm{h}}, \mathrm{DEG} / \mathrm{G}=4(5.5 \mathrm{~mL}$ containing $0.5 \mathrm{~mL}$ of I\% PVA and $5 \% \mathrm{NaCl}$ ); $\mathrm{W}_{2}, 5 \% \mathrm{NaCl} 1000 \mathrm{~mL}$; oil phase $10 \%$, $1200 \mathrm{mg}$ of dichloromethane solvent; formulation I, PLGA (2A50/50)/LPLA = 40/80; formulation II, PLGA (2A50/50)/HPLA = 40/80; formulation III, PLGA (3A50/50)/ LPLA = 40/80; formulation IV, PLGA (3A50/50)/HPLA = 40/80

Abbreviations: BSA, bovine serum albumin; PLGA, poly(lactic-co-glycolic acid); LPLA, low viscosity polylactide (molecular weight 60,000); HPLA, high viscosity polylactide (molecular weight 83,000); PVA, poly(vinyl alcohol); $O_{h}$, hydrophilic oil; DEG/G, ethylene glycol/glycerol; $\mathrm{NaCl}$, sodium chloride; $\mathrm{W}_{1}, 1 \% \mathrm{PVA}$ and $5 \% \mathrm{NaCl}$ water solution; $\mathrm{W}_{2}, 5 \% \mathrm{NaCl}$ water solution; $\mathrm{w} / \mathrm{w}$, trehalose $1 \%$.

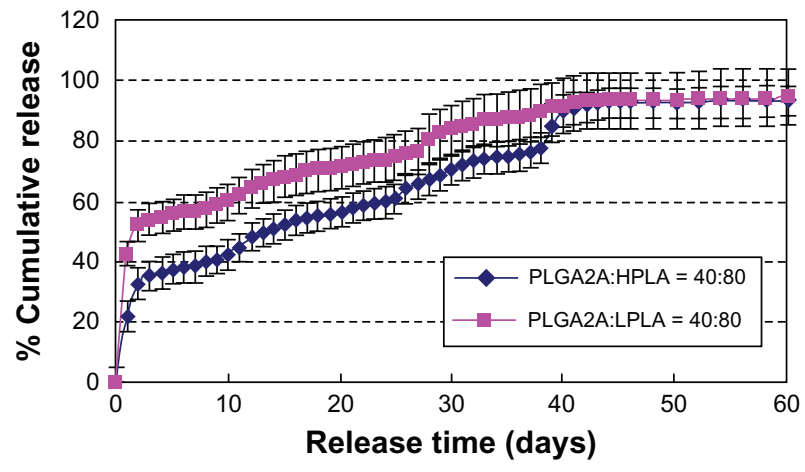

Figure 10 Effect of PLGA/PLA ratio on release in vitro. $W_{1}, 5 \% \mathrm{w} / \mathrm{w}$ BSA and dextran (BSA to dextran $6 \mathrm{mg}: 6 \mathrm{mg}$ ) water solution; $\mathrm{O}_{\mathrm{h}}$, DEG/G $=4(5.5 \mathrm{~mL}$ containing $0.5 \mathrm{~mL}$ of I\% PVA and $5 \% \mathrm{NaCl}$ ); $\mathrm{W}_{2}, 5 \% \mathrm{NaCl} 1000 \mathrm{~mL}$; oil phase $10 \%$, 1200 mg of dichloromethane solvent; formulation I, PLGA (3A50/50)/HPLA = 40/60; formulation II, PLGA (3A50/50)/HPLA = 40/80.

Abbreviations: BSA, bovine serum albumin; PLGA, poly(lactic-co-glycolic acid); HPLA, high viscosity polylactide (molecular weight 83,000); PVA, poly(vinyl alcohol); $O_{h}$, hydrophilic oil; $D E G / G$, ethylene glycol/glycerol; $\mathrm{NaCl}$, sodium chloride; $\mathrm{W}_{1}, \mathrm{I} \% \mathrm{PVA}$ and $5 \% \mathrm{NaCl}$ water solution; $\mathrm{W}_{2}, 5 \% \mathrm{NaCl}$ water solution; $w / w$, trehalose $1 \%$; PLA, polylactide.

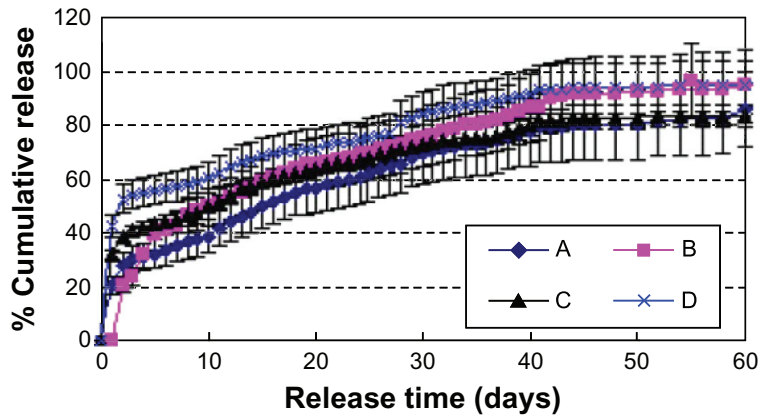

Figure II Effect of different $O_{h}$ on release in vitro $(n=3) . W_{1}, 5 \% w / w$ BSA and dextran (BSA to dextran ratio $6 \mathrm{mg}: 6 \mathrm{mg}$ ) water solution; $\mathrm{O}_{\mathrm{h}}, \mathrm{PG} / \mathrm{G}=4(5.5 \mathrm{~mL}$ containing $0.5 \mathrm{~mL}$ of $1 \%$ PVA and $5 \% \mathrm{NaCl}$ ); $\mathrm{W}_{2}, 5 \% \mathrm{NaCl} 1000 \mathrm{~mL}$; oil phase $10 \%$, $1200 \mathrm{mg}$ of dichloromethane solvent; formulation A, PLGA (3A50/50)/LPLA = 40/80; formulation B, PLGA (3A50/50)/HPLA = 40/80.

Abbreviations: BSA, bovine serum albumin; PLGA, poly(lactic-co-glycolic acid); HPLA, high viscosity polylactide (molecular weight 83,000); PVA, poly(vinyl alcohol); PG/G, I, 2-propylene glycol/glycerol; $O_{h}$, hydrophilic oil; $\mathrm{NaCl}$, sodium chloride; $\mathrm{W}_{1}, 1 \% \mathrm{PVA}$ and $5 \% \mathrm{NaCl}$ water solution; $\mathrm{W}_{2}, 5 \% \mathrm{NaCl}$ water solution; w/w, trehalose I\%; LPLA, low viscosity polylactide (molecular weight 60,000$)$.

\section{Conclusion}

In this study, we developed a novel method for preparation of sustained-release drug-encapsulating microspheres using a w/o/o $/ \mathrm{o}_{\mathrm{h}} / \mathrm{w}$ emulsion. We selected a hydrophilic oil phase to replace the second water phase (containing PVA and $\mathrm{NaCl}$ ) used in our previous research to extend the formulation method s/o/o/e. Use of hydrophilic oil was helpful for avoiding dissolution of particles and thereby increasing the protein EE. This also helped to avoid the dissolved protein from coming into contact with the oil-water surface, which could denature the proteins. We investigated many factors which might affect the 
morphology, size distribution, EE, and release profiles of the microspheres, and found that the hydrophilic and hydrophobic properties of the different materials used and the hydrophilic oil phase were key factors. Composite microspheres, with spherical morphology, suitable particle size, and good drug stability during the formulation steps and in vitro release, were successfully formulated.

This research has helped to resolve the technical issues involved in preparation of sustained-release microspheres for encapsulating drugs. PLGA is a biocompatible material, and has been used in clinical applications for many years. When PLGA microspheres are $20-100 \mu \mathrm{m}$ in size, they usually inhibit uptake of cells and depend only on degradation and uptake of PLGA.

This novel method may enhance the bioactivity and EE of proteins because of the decreased interface between oil and water. The materials are often modified to be more hydrophilic in order to enhance the bioactivity and EE of proteins. We have developed a new method to address this problem by adding a hydrophilic oil phase and decreasing the amount of protein directly in contact with the interface between oil and water.

\section{Acknowledgments}

The study was supported by the Projects of National Science Foundation of China (81071025, 81171203 and 81171204) and Projects of the Shanghai Committee of Science and Technology, People's Republic of China (11nm0503300, 11410708900, 12XD1403800).

\section{Disclosure}

The authors declare that they have no competing interests in this work.

\section{References}

1. Jorgensen L, Moeller EH, van de Weert M, Nielsen HM, Frokjaer S. Preparing and evaluating delivery systems for proteins. Eur J Pharm Sci. 2006;29(3-4):174-182.

2. Castellanos IJ, Cruz G, Crespo R, Griebenow K. Encapsulation-induced aggregation and loss in activity of $\gamma$-chymotrypsin and their prevention. J Control Release. 2002;81(3):307-319.

3. Coombes AGA, Yeh MK, Lavelle EC, Davis SS. The control of protein release from poly(dl-lactide co-glycolide) microparticles by variation of the external aqueous phase surfactant in the water-in oil-in water method. J Control Release. 1998;52(3):311-320.

4. Lu W, Park TG. Protein release from poly(lactic-co-glycolic acid) microspheres: protein stability problems. PDA J Pharm Sci Technol. 1995;49(1):13-19.

5. Park TG, Lee HY, Nam YS. A new preparation method for protein loaded poly(d,1-lactic-co-glycolic acid) microspheres and protein release mechanism study. J Control Release. 1998;55(2-3):181-191.
6. Morita T, Sakamura Y, Horikiri Y, Suzuki T, Yoshino H. Protein encapsulation into biodegradable microspheres by a novel $\mathrm{S} / \mathrm{O} / \mathrm{W}$ emulsion method using poly(ethylene glycol) as a protein micronization adjuvant. J Control Release. 2000;69(3):435-444.

7. Rong X, Mo X, Ren T, et al. Neuroprotective effect of erythropoietinloaded composite microspheres on retinal ganglion cells in rats. Eur $J$ Pharm Sci. 2011;43(4):334-342.

8. Hu Z, Liu Y, Yuan W, Wu F, Su J, Jin T. Effect of bases with different solubility on the release behavior of risperidone loaded PLGA microspheres. Colloids Surf B. 2011;86(1):206-211.

9. Ren T, Yang X, Wu N, Cai Y, Liu Z, Yuan W. Sustained-release formulation of levodopa methyl ester/benserazide for prolonged suppressing dyskinesia expression in 6-OHDA-lesioned rats. Neurosci Lett. 2011;502(2):117-122.

10. Ren T, Yuan W, Zhao H, Jin T. Sustained-release polylactide-co-glycolide microspheres loaded with pre-formulated protein polysaccharide nanoparticles. Micro Nano Lett. 2011;6(2):70-74.

11. Wu F, Yuan W, Su J, Ren J, Jin T. Preparation and characterisation of PLGA microspheres for sustained release of recombinant human granulocyte colony-stimulating factor. Micro Nano Lett. 2011;6(4):181-185.

12. Yuan W, Ren T, Wu F, Zhao H, Jin T. A novel preparation method for microspheres by glycerol modified solid-in-oil-in-water multi-emulsion. Polym Adv Technol. 2010;21(5):371-376.

13. Yuan W, Zhang Y, Wu F, et al. Preparation of protein-loaded sustained-release microspheres via 'solid-in-oil-in-hydrophilic oilin-ethanol (S/O/hO/E)' emulsification. Colloids Surf B. 2010;79(2): 326-333.

14. Carrasquillo KG, Staneley AM, Aponte Carro JC, et al. Non-aqueous encapsulation of excipient-stabilized spray-dried BSA into poly(lactideco-glycolide) microspheres results in release of native protein. J Control Release. 2001;76(3):199-208.

15. Wang N, Wu XS. A novel approach to stabilization of protein drugs in poly(lactic-co-glycolic acid) microspheres using agarose hydrogel. Int J Pharm. 1998;166(1):1-14.

16. Yuan W, Wu F, Guo M, Jin T. Development of protein delivery microsphere system by a novel S/O/O/W multi-emulsion. Eur J Pharm Sci. 2009;36(2-3):212-218.

17. Yuan W, Liu Z. Controlled release and preserved bioactivity of proteins from (self-assembled) core-shell double walled microspheres. Int $J$ Nanomedicine. 2012;7:257-270.

18. Yuan W, Wu F, Geng Y, Xu S, Jin T. The preparation of dextran glassy particles through freezing induced phase separation. Int $J$ Pharm. 2007;339(1-2):76-83.

19. Yang $\mathrm{S}$, Yuan W, Jin T. Formulating protein therapeutics into particulate forms. Expert Opin Drug Deliv. 2009;6(10):1123-1133.

20. Xu D, Hu Z, Su J, Wu F, Yuan W. Micro and nanotechnology for intracellular delivery therapy protein. Nano Micro Lett. 2012;4(2):118-123.

21. van de Weert M, Hennink WE, Jiskoot W. Protein instability in poly(lactic-co-glycolic acid) microparticles. Pharm Res. 2000;17(10): $1159-1167$.

22. Bao W, Zhou J, Luo J, Wu D. PLGA microspheres with high drug loading and high encapsulation efficiency prepared by a novel solvent evaporation technique. J Microencapsul. 2006;23(5): 471-479.

23. Schoubben A, Blasi P, Giovagnoli S, Perioli L, Rossi C, Ricci M. Novel composite microparticles for protein stabilization and delivery. Eur $J$ Pharm Sci. 2009;36(2-3):226-234.

24. DeYoung MB, MacConell L, Sarin V, Trautmann M, Herbert P. Encapsulation of exenatide in poly-(D,L-lactide-co-glycolide) microspheres produced an investigational long-acting once-weekly formulation for type 2 diabetes. Diabetes Technol Ther. 2011;13(11): $1145-1154$.

25. Han Y, Tian H, He P, Chen X, Jing X. Insulin nanoparticle preparation and encapsulation into poly(lactic-co-glycolic acid) microspheres by using an anhydrous system. Int J Pharm. 2009;378(1-2): 159-166. 
26. Checa-Casalengua P, Jiang C, Bravo-Osuna I, et al. Retinal ganglion cells survival in a glaucoma model by GDNF/Vit E PLGA microspheres prepared according to a novel microencapsulation procedure. J Control Release. 2011;156(1):92-100.
27. Liu G, Hong X, Jiang M, Yuan W. Microspheres of sustained-release G-CSF by a novel solid-in-oil-in-oil-in-water multi-emulsion. Int $J$ Nanomedicine. 2012;7:4559-4569.

\section{Publish your work in this journal}

The International Journal of Nanomedicine is an international, peerreviewed journal focusing on the application of nanotechnology in diagnostics, therapeutics, and drug delivery systems throughou the biomedical field. This journal is indexed on PubMed Central, MedLine, CAS, SciSearch $\AA$, Current Contents ${ } /$ Clinical Medicine,
Journal Citation Reports/Science Edition, EMBase, Scopus and the Elsevier Bibliographic databases. The manuscript management system is completely online and includes a very quick and fair peer-review system, which is all easy to use. Visit http://www.dovepress.com/ testimonials.php to read real quotes from published authors.

Submit your manuscript here: http://www.dovepress.com/international-journal-of-nanomedicine-journal 